\title{
Merging the E-journaling and the Workshop Methods to Reduce Prep-Year Students' Writing Apprehension: An Experimental Study
}

\author{
Osama Mohammed, "Ph.D.” (Corresponding author) \\ Instructor of English, Head of Quality Dept., ELC, Taibah University \\ Janadah Bin Umayyah Road, PO Box 344, Medina 42353, Saudi Arabia
}

Tel: 966 (50 282 2711) - (54 988 6718) E-mail: omohammed@ taibahu.edu.sa

\begin{abstract}
Waleed Othman, "Ph.D."
Instructor of English, Head of Language Support Unit, ELC, Taibah University

Janadah Bin Umayyah Road, PO Box 344, Medina 42353, Saudi Arabia

E-mail: celtaholder1@gmail.com
\end{abstract}

\begin{abstract}
Bakare Kazeem Kayode, "Asst. Prof."
Faculty of Education, Al-Madinah International University (MEDIU)

E/9E 2, Jalan Tengku Ampuan Zabedah 40100, Shah Alam, Selangor, Malaysia

E-mail: bakare.kazeem@mediu.edu.my
\end{abstract}

Received: December 5, 2019 Accepted: January 28, 2020 Published: January 30, 2020

doi:10.5296/ijele.v8i1.16358 URL: https://doi.org/10.5296/ijele.v8i1.16358

\begin{abstract}
Preparatory (prep) year students presently encounter a significant disparity between prior to college English writing and the much superior level of competence needed for potential academic programs in Saudi Arabia. Study has verified the operational efficacy of the methods of e-journaling and writing workshop on alleviating writing apprehension but on a separate basis. This study represents an original contribution to knowledge through exploring the effects of merging these two outstanding methods. Accordingly, the degree to which this new method reduced Saudi prep-year students' writing apprehension was statistically examined. Tools
\end{abstract}




\section{Macrothink}

included an instructional program and a writing apprehension test. The researcher applied the randomized control-group posttest-only design in the experiment. Students were randomly assigned to an experimental group, that studied the new program and a control group, that did not experience such treatment. At the end of the experiment, the two groups were post-tested using the writing apprehension test. Statistical treatment of the results was carried out, and the findings revealed that there is a statistically substantial difference between mean scores in favor of the experimental group students. This indicates that the integration of the e-journaling and the writing workshop methods has substantial effects on minimizing students' writing apprehension as compared to the control group students. Further research is needed to develop new consistent methods of teaching writing that cope with and benefit from the current digital outbreak, especially in the Saudi, Arab and EFL foundation/prep-year contexts.

Keywords: EF/SL, ELT, writing apprehension, writing workshop, e-journaling, undergraduate students, Saudi universities 


\section{Introduction}

\subsection{Research Background}

Despite its reputation as an extremely essential skill, writing fails to hold a worthy rank in language programs as reported by several research studies (See, for instance, White, 1991; Badger, 2000; Dempsey et al., 2009; Arju, 2019). Correspondingly, it is extensively recognized that writing efficiency hinges on both the writing atmosphere and learner individualities (Lin, 2014; Chen, 2016; Chun et al., 2016). Those individualities incorporate learning objectives, standards, attitudes, and learning records (Strobl, 2017). Despite its importance, English in the Arab world is generally taught only as a school subject and as a foreign language as opposed to being used as the main language of teaching (Al-Mohanna, 2010). A good example of this can be found in Saudi Arabia.

A considerable amount of writing, in EFL learners' personal and social lives, is online (Chun, Kern, \& Smith, 2016). They call for an extensive range of writing skills and field awareness, from relating the applicable language record when involving themselves in social media to confirming language is simply accurate in writing proper details. For achievement in countless arenas, innovative writing skills are required (Vandommele, Van den Branden, Van Gorp, \& De Maeyer, 2017). L2 instructors should catalyze learners in acquiring the technicalities of writing and in being capable of writing analytically in all aspects (Chun et al., 2016). Everyone who teaches writing in a foreign context is confronted with the problem of writing apprehension. Matthews (2016, p5) adds that "writing apprehension is real and should be addressed in the classroom". Resulting from this hatred of writing is the problem of students' worry and nervousness about writing (Cargill, 2019). Al-Ahmad (2013) states that writing apprehension has constituted a difficult challenge to both native and non-native English student writers as well as their writing instructors, and negatively affected their writing performance. Accordingly, many researchers conducted studies concerned with revealing writing apprehension among students. One of those is Gamboa and Buitrago (2018) who contends that writing apprehension is a problem because it has consequences for students' learning experience, and for the decision they make about engaging in meaningful, productive writing projects.

\subsection{Statement of the Problem}

Prep-year students face a substantial gap between prior to university English writing and the much higher level of proficiency needed for their prospective academic programs in Saudi Arabia, nowadays. Significantly, abundant research conducted in many Arab countries has reported that Arab university students struggle with serious distress in English language, generally and writing specifically (Hassan, 2001; Aly, 2002; El Said, 2006; Awan et al., 2010; Basha, 2012; Al-Ahmad, 2013; Rabab'ah, 2013; Alzaanin, 2014; Huwari's, 2014; Tahaineh, 2015; Khalil, 2016; Obeiah \& Bataineh, 2016; Abrams, 2019, and Al-Hroub et al., 2019). Respectively, there is a need to devise practices that would reconcile the present situation specifically, that can help students overcome their fear of writing and improve their writing ability in English as a foreign language. This makes it imperative for instructors of English to try to experiment with new directions in their pursuit of development. Thus, it is hypothesized that the challenge of incoming first-year students' lack of university-level writing abilities 
could be tackled by an innovative 7-week program that merges the e-journaling and the writing workshop techniques. This may relieve prep-year program students' writing apprehension.

\subsection{Research Objective and Question}

The aim of this study is to examine any statistically substantial differences in:

- Prep-year students' writing apprehension mean scores for control and experiment groups before and after introduction of the e-journaling and writing workshop approach.

Respectively, the current study seeks to find an answer to the following research question:

- Are there any differences in prep-year students' writing apprehension mean scores for control and experiment groups before and after introduction of the e-journaling and writing workshop approach?

In harmony with the posed question above, the following null hypothesis is derived:

- There are no statistical differences in prep-year students' writing apprehension mean scores for control and experiment groups before and after introduction of the e-journaling and writing workshop approach.

\subsection{Definition of Terms}

- Writing Apprehension

Williams (2000, p.22 as cited in El Said, 2006) asserts, "Writing apprehension involves anxiety associated with writing situations, a tendency to avoid such situations, frustration, and low productivity while writing. It also involves quite enduring tendencies to dislike or fear writing."

In the same direction, Bloom (1984, p 72) declares that individuals with extra apprehension of writing escape from writing every time they can. They strive for jobs, university programs, and pedagogy requiring slight writing and evade positions that require writing. They dread assessment of their writing, believing that they will get low marks on it (El Said, 2006). They assume to be unsuccessful in writing and steadily cut writing lessons and disregard to submit their assignments.

In the current study, writing apprehension represents the high point of anxiety and panic of writing that appears via performances of escaping of writing tasks and emotions of frustration when requested to write. Learners assume that they will get the lowermost grades on writing, or they cannot begin writing completely.

This definition emphasizes two sides of the writing apprehension:

1. Assessment apprehension where students anticipate writing below par, so the instructor will provide them low grades.

2. Anxiety apprehension wherever students have trouble in conveying their ideas.

- The Writing (or Writers') Workshop

Massengill (2001, p15) defined the writing workshop as "an organizational approach to writing in the classroom that catalyzes the recursive nature of writing by adopting a process approach." El Said (2006, p.12) defined the writing workshop as a student-centered approach to teaching 


\section{Macrothink}

writing in a social context. Students learn in an environment that employs modeling and coaching where the instructor is a guide and facilitator of students' learning. Typically, there is a mini lesson at the beginning followed by stages of writing and rewriting after which students come to a sharing time to celebrate their work.

For the current study, writing workshop signifies a student-centered method of teaching writing in a communal setting. Learners study in an atmosphere that encourages modeling and coaching where the instructor is a guide on the side (not a sage on the stage) and an initiator of students' learning. Characteristically, there is a mini lesson at the start followed by phases of writing and rewriting then learners enjoy sharing their work.

This definition emphasizes:

1. The energetic role of the student as the center of learning.

2. The facilitating role of the instructor as a guide and a monitor.

3. The communal and communicative nature of writing.

- E-journaling

An instructive approach that efficiently improves self- awareness, student concern, and on-line learning in and out of the classroom (Conhaim \& Page, 2013).

In the current study, e-journaling is learning writing through journaling which done electronically either on or off-line. This electronic learning approach to journaling depends on using a computer, a mobile phone, a tablet or any other electronic communication device/application through many forms like:

1. E-mails or Discussion boards

2. Weblogs or Blogs

3. What's App or Tango

4. Twitter or Facebook

This definition stresses the active influence of e-journaling on meeting several learning aims by:

1. Allowing students to develop reflective writing practice skills in an enjoyable way.

2. Fostering learning from course resources and from other learners as well.

3. Tolerating reluctant learners to express themselves along with their skills.

4. Giving learners extra time to consolidate their views before posting them online.

5. Building rapport between instructors and students.

6. Alleviating problems with poor handwriting.

7. Giving accessibility around the clock for both learners for writing and instructors for marking.

\subsection{Delimitations of the Study}




\section{Macrothink Institute ${ }^{\mathrm{TM}}$}

1. The study comprised a seven-week teaching program that merged the e-journaling and the writing workshop methods thru semester one 2018-2019 G.

2. It was limited to lowering writing apprehension.

3. The study sample was restricted to two male classes (so no findings could be credited to the gender variable), randomly selected from the population of (PYP) students at Taibah University (ranged between 17 and 19 years old).

\section{Literature Review}

\subsection{Theoretical Framework}

According to Hodges (2017), not a single theory covers all that is writing at present. For instance, the cognitive theory expounds what happens in learners' brains during writing; however, it overlooks external effects, such as motivation, involvement, and communal impact. On the other hand, sociocultural theory elucidates how learners' culture and communal interactions affected their involvement in writing; nonetheless, it ignores what happens in a learner's mind through the writing practice (Zheng \& Warschauer, 2018). Out of this prospect, the researcher looked closely over the theory behind L2 teaching of writing along with the models of writing workshop and e-journaling according to the following levels of abstraction demonstrated in figure (1) below.

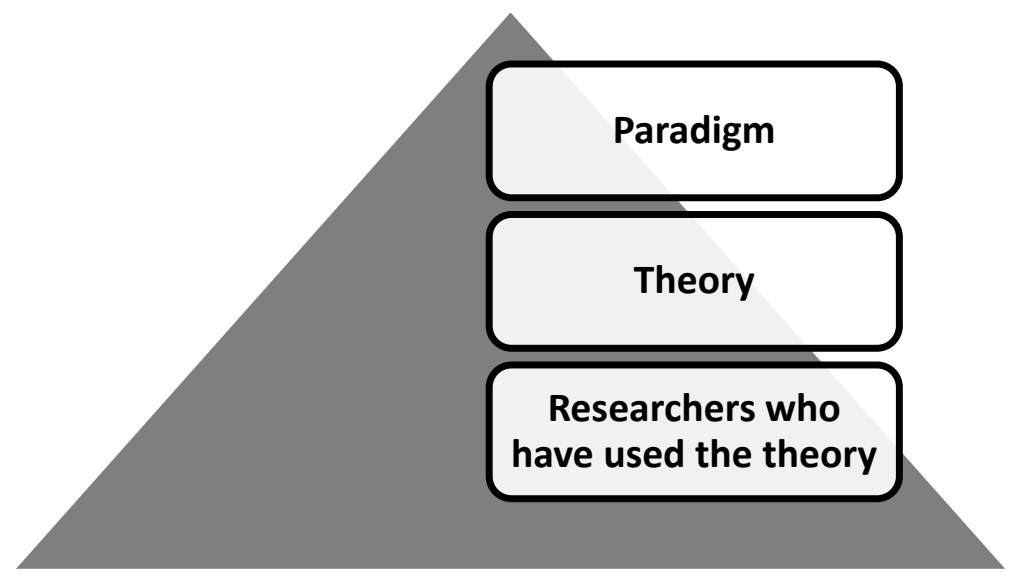

Figure (1) The theoretical framework levels of abstraction

According to Phinney (1991), second language writers are often assumed to have more apprehension than first language writers, to monitor their output more, to be likely to edit prematurely and to have more negative attitudes toward writing in their second language than first language writers do. Peyton (1994) contend that they may be afraid of writing and be reluctant to write, stemming from a sense of language deficiency. In other words, they presume that they are incompetent in a foreign language so they will not be able to write it. Cargill (2019) also adds that ESL student writers have all the worries of the native speaker and many more besides, for all of them have to acquire or consciously learn the phonology, grammar, syntactic structure, vocabulary, rhetorical structure, and idiom of a new language in addition to learning the mechanics of prose. These factors together foster the creation of writing apprehension with second language student writers. 


\section{MInstitute ${ }^{\text {Mank }}$}

Through merging the workshop and the e-journaling techniques, the present study tries to positively build on the advantages and effectively handle the concerns in order to develop prep-year students' writing skills. This recipe would promote writing as a communal practice that results from genuine interaction between two or more people and provide students a more inspiring objective for practicing writing. Graham and Perin (2018) assert that "regardless of the variety of communicative didactics, their purpose remains to prepare learners to use the second language in the world beyond" (p.15). The following section sheds some light on e-journaling, its theoretical framework, core structure, advantages, and glitches, as well as how it can efficiently complement the writing workshop technique.

\subsection{Previous Studies}

Researchers have endeavored to reduce English learners' writing apprehension as a severe challenge that could hinder their writing progress. For instance, Hassan (2001) performed a study to delineate if both writing apprehension and self-esteem of EFL university students are related to the quality and quantity of their writing. The writing apprehension of the EFL university students negatively correlated with their self-esteem. The study suggested that writing skills improvement courses should be taught in non-traditional methods. To lower writing anxiety levels among students, it was also suggested that instructor evaluation be reduced and replaced with peer or self-evaluation whenever possible.

Song's (2007) experimental study investigated the effect of dialogue journal writing on the writing quality, reading comprehension, and writing apprehension of Korean college students who learn English as a foreign language. Variables analyzed were: (1) Change in writing quality, measured by holistic rating. (2) Change in reading comprehension, measured by the comprehension subtest of TOEFL. (3) Change in writing apprehension scores as measured by Daly and Miller's Writing Apprehension Test. Results showed that the difference in writing apprehension reduction was not statistically substantial, although the gains favored the dialogue journal-writing group.

Awan et al. (2010) performed a study to define the outcome of using peer review groups in teaching essay writing to fourth-year English majors, Faculty of Education for girls, Al-Baha, Saudi Arabia, on their writing performance, apprehension, revising and attitudes towards peer review groups. The study had a pre/post control group design. Tools of the study incorporated a composition grading scale, a writing apprehension scale (the Daly-Miller WAT), an attitude scale towards peer review groups and the Michigan Test of English Language Proficiency. Results of the study revealed that students' writing apprehension lessened substantially.

Al-Ahmad (2013) conducted a study in which he employed a collaborative approach to learning which was assumed to reduce students' writing apprehension. In this approach, student writers work collaboratively in groups to explore, analyze, and negotiate to mean and solve problems in a non-threatening atmosphere. The result showed that students' writing apprehension had decreased substantially. Additionally, their attitudes toward writing had positively changed. Substantial correlations were also found between instructors, attitudes and collaborative learning in both L1 and L2 samples. However, the findings revealed no substantial gender differences. 
Matthews (2016) performed a study, which developed a pedagogical approach for reducing writing apprehension. Like this study, the Daly-Miller Writing Apprehension Test was administered as a pre-test and a post-test. All three major participants, two apprehensive and one unapprehensive, had scores which reflected a reduction in apprehension on the post-test. In addition, through classroom observations and interviews with the major participants, it was also evident that they viewed the writing process more positively than they had done before.

Significantly, Lew and Tang (2017) study investigated writing apprehension in ESL students. It examined students' feelings toward writing and tested procedures to lower apprehension. Gender and language differences were compared, and the results of highly apprehensive students were discussed. The findings showed that 1) highly apprehensive ESL writing students didn't avoid advanced composition classes; 2) male ESL writers were more apprehensive than female; 3) ESL writers worried more about form than content; 4) relaxation exercises reduced writing apprehension.

The study of Arju (2019) examined correlations between writing L2 writing teaching methods and students writing achievement and apprehension. Arju used an English Writing Apprehension Questionnaire and a 50-minute writing task. Statistical analyses incorporated Pearson product-moment correlations, a series of $t$-tests, and two-track analyses of variance. Outcomes displayed that the inspirational inducements of well-planned pre-writing pedagogy supported EFL students in getting over their writing apprehension and improving their writing skills.

\subsection{The Impact of the Literature Review on This Study}

There seems to be much evidence that merging the e-journaling and the writing workshop techniques can develop learners writing abilities in relation to their writing production skills, specifically, content/organization styles, usage, and mechanics. These techniques catalyze learners to take the lead over their learning communicatively. Finally, there is also evidence that these approaches help students help themselves get rid of many bad habits that used to prevent them from expressing themselves fluently, such as fear of making mistakes and their concentration on usage and mechanics instead of content and style. The writing workshop model is principally based on the process approach about fostering an atmosphere that encourages modeling and coaching where the instructor initiates students' lifelong learning as a guide on the side rather than a sage on the stage. Essentially, in regular blocks of time, instructors begin with a mini lesson, followed by periods of drafting, conferencing and sharing, revising, redrafting, editing, publishing and celebrating, as emerged from the following associations:

1. The workshop process approach vs. the traditional approach

2. Core and construction of the writing workshop model

3. Instructors and students' roles in the writing workshop

4. Advantages and challenges of the writing workshop

E-journaling is typically looked at as an innovative method of teaching writing that cope with and benefit from the current digital outbreak especially in the areas of critical thinking and writing improvement. Some of its familiar thoughts and concerns are positively tackled in a 


\section{Macrothink}

way that can assist in initiating further enjoyable lifelong EFL learning, as follows:

1. E-journaling versus traditional journaling

2. Core and structure of the e-journaling model

3. Instructors and students' roles in the e-journaling context

4. Advantages and disadvantages of the e-journaling model

Out of this prospect, the reviewed research verified the effectiveness of the writing workshop $\&$ e-journaling methods, but on a separate basis. They can fortify the social nature of language in line with its cognitive feature (Gee, 2000; Wang, 2015; Zheng \& Warschauer, 2018). Apprehension impact on quantity\&/quality of L1\&L2 students writing was widely examined (Song, 2007; Lew \& Tang, 2017; Arju, 2019). Few studies addressed the writing apprehension of Arabic learners e.g. (Aly, 2002; Obeiah, 2016; Al-Hroub, et al., 2019). Most research found targeted pre-university students \& special education, e.g. (Wyatt, 2009; Sim \& Hew, 2010; Cargill, 2019). Here comes the original contribution to knowledge, of this study, through devising a digitally collaborative method to bridge the aptitude gap of PYP students thru reducing their writing apprehension.

\section{Methodology}

\subsection{Research Design}

The present study adopted the true experimental research design through the application of the randomized control-group posttest-only design. The experimental group students studied the new program while the control group students did not experience such treatment. At the end of the experiment, the two groups were post-tested using the writing apprehension test as follows:

Group

Randomization (R) \{
Treatment

A
Post-testing

$\mathbf{X}$
$\mathbf{O}$

\subsection{Population and Sampling}

The students of the preparatory year program (PYP) at Taibah University represent the population of the study. A sample size of 78 students was randomly obtained, from a population of 97 registered prep-year students, using raosoft online calculator, with a 95\% confidence level, a 5\% margin of error and a 50\% response distribution (39 students in each class). The writing apprehension test utilized in the study was implemented to the experimental group and the control group students prior to the application of the program. Using $t$-test formula for independent samples, means of scores obtained by the students of the experimental group and the control group revealed no statistically substantial difference, as shown in the table below. 
Table (1)

Pre-testing $t$-test results of students' writing apprehension

\begin{tabular}{|c|c|c|c|c|}
\hline Group & $\begin{array}{c}\text { Number of } \\
\text { students }\end{array}$ & $\begin{array}{c}\text { Mean } \\
\text { score }\end{array}$ & $\begin{array}{c}\text { Standard } \\
\text { deviation }\end{array}$ & $\begin{array}{c}\text { Observed } \\
\text { t-value }\end{array}$ \\
\hline Control & 39 & 39.87 & 11.12 & \multirow{2}{*}{1.27} \\
\hline Experimental & 39 & 36.79 & 10.38 & \\
\hline
\end{tabular}

$$
\mathrm{P} \leq .05
$$

\subsection{Research Instrument and Procedures}

As Creswell (2009) warned against the false variations, which can be triggered by the treatment in the randomized control-group posttest-only design, the researcher precisely constructed these tools.

The Writing Apprehension Test:

The researcher adapted and statistically verified the Daly-Miller (1975) Writing Apprehension Test, often referred to as "WAT", to suit the levels of the Prep-Year Program students. It was first translated and validated for the Arabian context by El Said (2006). Items included anxiety about writing along with worry about instructor and peer evaluation of writing (Awan et al., 2010).

The experimental teaching program, which incorporated:

a. An interactive design which included the following stages and strategies:

- Mini-lesson (a short lesson gave direct instruction of a certain feature or skill of writing)

- Prewriting (where students brainstormed and collected information about the topic)

- Writing the first draft (using their generated ideas freely without bothering accuracy)

- Revising (making necessary changes regarding the content and organization of ideas)

- Editing (fixing mechanical and structural mistakes in grammar, spelling, and punctuation)

- Author's circle (where all listened carefully and gave feedback to the promising author)

- Whole-class e-journaling (celebrating students' attainment via publishing their writings)

b. Actionable teaching guidelines and techniques thru the instructor's handbook.

c. Enjoyable lifelong activities via the student's workbook, as shown in figure (2) below. 


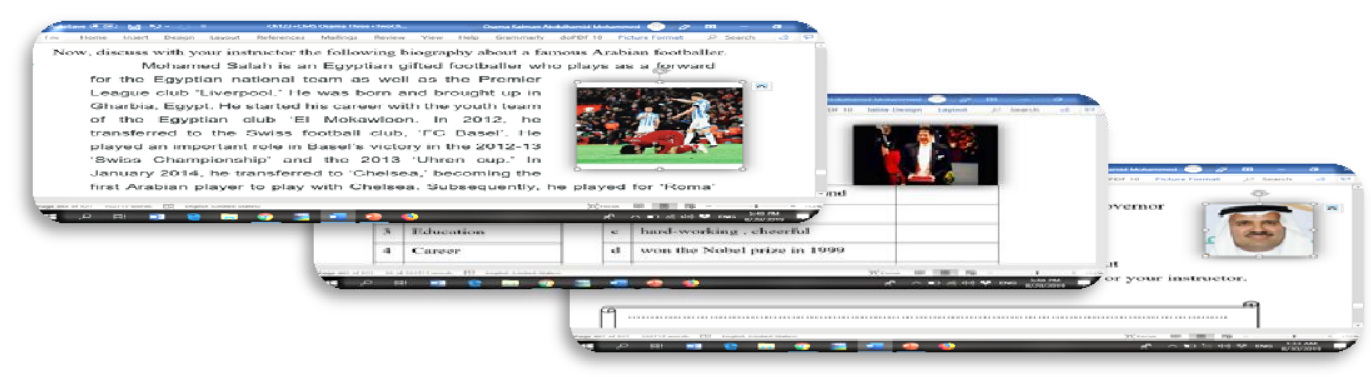

Figure (2) Real-life motivating samples of student workbook lessons

\subsection{Validity and Reliability}

a. The experimental program and performance test were submitted to a jury of TEFL experts.

b. They appraised them as being valid and suitable for the purpose they were designed for with few suggestions and modifications.

c. The researcher adapted the counsels in the final form of the program and performance test.

d. The writing apprehension test reliability was calculated by utilizing the test-retest method. Scores obtained from the first administration were correlated with scores obtained from the second administration using Pearson Formula as well as Spearman-Brown Formula. The reliability coefficient was .95 on both formulas.

\subsection{Pilot Study}

The pilot test covered all the instruments of the study. Four representative lessons of the program were administered to a randomly chosen prep-year class of 35 students (other than the two classes participating in the main experiment of the study). These lessons incorporated: a) What was a paragraph. b) Writing an e-mail, c) Describing a person, and d) Telling a story. These lessons represented the core of the program as each lesson represents the unit from which it was selected. The four units of the program were thus represented. Students were given a comprehensive picture of the whole experimental program. The pilot study took two weeks starting on September 9, 2018 and ending on September 20, 2018. The pilot study of the program aimed at:

a. Testing the applicability of the materials and the pedagogy set for teaching.

b. Diagnosing problems that appeared and suggesting suitable solutions.

c. Deciding on the suitability of the activities and program content for students' level.

d. Preparing a suitable timeline and schedule for every session and the program.

\subsection{Variables and Measurement}

Together piloting the study as well as dealing effectively with some inconveniencies through its administration, helped the researcher greatly in the application of the experiment of the program along with the designation of its variables and measurement as follows.

The independent variable:

- A seven-week program merging the methods of e-journaling and writing workshop. 
The dependent variable:

- The prep-year program students' writing apprehension.

To achieve homogeneity between the students of the experimental and the control groups, the following variables were controlled:

- The study population represented the same socio-economic background and status.

- The classes were taught by the same instructor (rather than the researcher) to eliminate:

a. The invalidity that could result from instructor difference.

b. The subjectivity that could result from the researcher.

- To achieve homogeneity of the two classes, the following variables were controlled:

a. Both groups were male classes, so no differences could be credited to gender.

b. Excluding repeaters, the students' age ranged from seventeen to nineteen years old.

- Students who came from private or language schools and repeaters were excluded.

\subsection{Data Collection Procedures}

To administer the experiment of the study, the researcher adopted these data collection procedures in line with Taibah University Pacing Schedule, ENG101, Semester 1, Academic Year 2018-2019:

1. An introductory meeting was held with the experimental group on September 30, 2018.

2. Program teaching was from October 7, 2018 to November 29, 2018 (two times a week).

3. The experimental and control groups took the apprehension test on December 4, 2018.

The apprehension test was used to compare the writing anxiety level of the experimental group students who were taught writing using a program based on merging both the e-journaling and the writing workshop approaches and the control group students who did not receive such treatment.

\section{Results}

The research question is: "Are there any differences in prep-year students' writing apprehension mean scores for control and experiment groups before and after the introduction of e-journaling and writing workshop approach?" The null hypothesis is: "There are no statistical differences in prep-year students' writing apprehension mean scores for control and experiment groups before and after the introduction of e-journaling and writing workshop approach." To examine this hypothesis, the researcher computed and formulated students' results on the writing apprehension test. Then, he applied the t-test formula for independent samples to establish the conclusion of the dissimilarity between mean marks of the experimental group and the control group learners as specified in figure (3) and table (2). 


\section{Macrothink}

Table (2)

Post-testing $t$-test results of students' writing apprehension

\begin{tabular}{|c|c|c|c|c|}
\hline Group & $\begin{array}{c}\text { Number of } \\
\text { students }\end{array}$ & $\begin{array}{c}\text { Mean } \\
\text { score }\end{array}$ & $\begin{array}{c}\text { Standard } \\
\text { deviation }\end{array}$ & $\begin{array}{c}\text { Observed } \\
\boldsymbol{t} \text {-value }\end{array}$ \\
\hline Control & 39 & 43.56 & 10.05 & \multirow{2}{*}{$6.78^{*}$} \\
\cline { 1 - 4 } Experimental & 39 & 59.74 & 10.99 & \\
\hline
\end{tabular}

$* \mathrm{P} \leq .05$

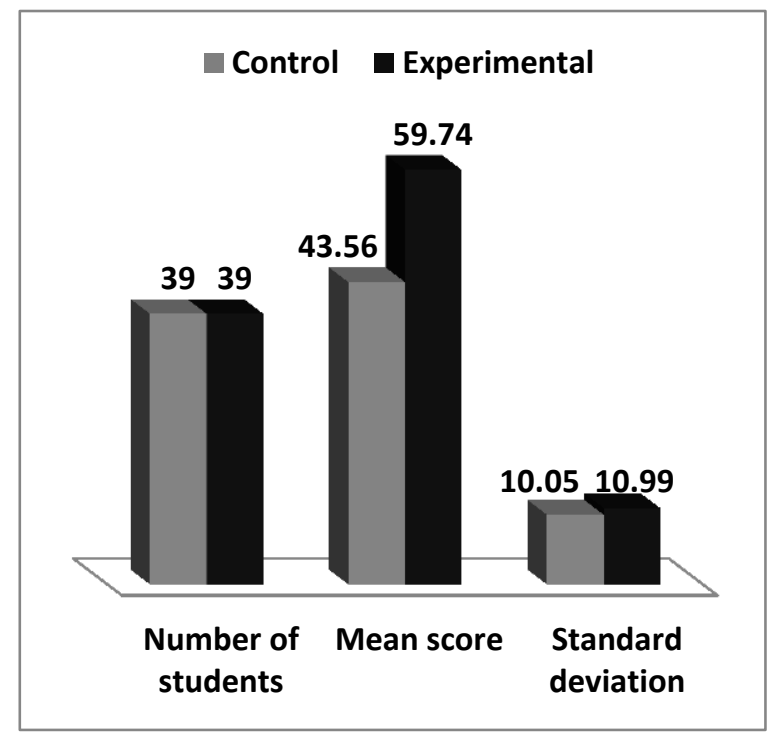

Figure (3) Post-testing results of students' writing apprehension

As the control group share with the experimental group students all other variables save the experimental treatment, the substantial reduction in the experimental group students' writing apprehension can be credited to the influence of the experimental treatment. Consequently, the null hypothesis was excluded, and the substitute hypothesis was admitted. This indicates that the integration of the e-journaling and the writing workshop approaches has substantial effects on minimizing the experimental group students' writing apprehension as compared to the control group students.

\section{Discussion}

In line with the literature review, the in-depth analysis of the scores verified the progress of experimental group students' writing skills and drop of their writing apprehension. These results can be attributed to the effective features of the e-journaling and writing workshop methods that were merged throughout the teaching program and cope with previous study through:

1. Promoting "the absent" enjoyable lifelong content and methodology (El Said, 2006; Ciampa, 2016; Abedi, Keshmirshekan \& Namaziandost, 2019). 


\section{Mll Macrothink}

2. Consolidating their writing acquisition and attitude positively (Smith \& Dirkx, 2007; Hicks, 2013; Agésilas, 2015; Kerr, 2017; Gamboa, 2018).

3. Developing students sense of authority, responsibility and self-confidence in learning (Hill, 2008; Sim \& Hew, 2010; Kerr, 2017).

4. Saving the instructor's time for more useful concerns "e.g. modeling and monitoring" (Rowen, 2005; Al-Mohanna, 2010; Wu et al., 2019).

5. Using cooperative techniques full of support "e.g. peer-reviewing, editing” (Dyment \& O'Connell, 2003; Leer \& Runck, 2016; Cohen, 2018).

6. Reinforcing the social nature of language in line with its individual feature (Tuan, 2010; Agésilas, 2015; Head et al., 2017; Cargill, 2019).

7. Creating student-centered environs that promoted autonomy and collaborative learning, “e.g. group editing, e-journaling, and publishing” (Aly, 2002; Kim, 2015; Arju, 2019).

Furthermore, the safe and positive environment the instructional program provided for the participants played an interactive part in the reduction of students' anxiety. For example, the mistakes that students made were not stressed from the beginning as it was done in traditional approaches. Instead, it was stressed that mistakes were natural and expected from all humans, and they can be viewed as indicators of development that could be handled through the following stages of the writing process, so students did not have to worry about them. Also, the discussions and exchanges that took place before and during the writing conferences showed the students that they all can make mistakes and they all can learn from each other's mistakes as well.

\section{Conclusions}

The findings of the current study can be attributed to the efficiency of the program merging the e-journaling and the writing workshop approaches, incorporated in the current study. Contrary to most locally based teaching of writing methods, in this program each lesson began with a mini lesson in which the instructor gave a theoretical introduction to provide the students with the information required in every lesson. In this part also, the students had the chance to listen to their instructor, ask about and feature any point they could not understand. At the end of each mini lesson, the instructor helped the students to take notes in their workbooks about the important points of the lesson. This feature of the program was a rich source of knowledge and information related to writing skills. It empowered them with the information necessary for improving their writing abilities and for getting ready for the final test of the program as well. The communicative setting of the classroom was also of crucial importance in improving the student-student and student-instructor interaction, as demonstrated in figure (4) below. 


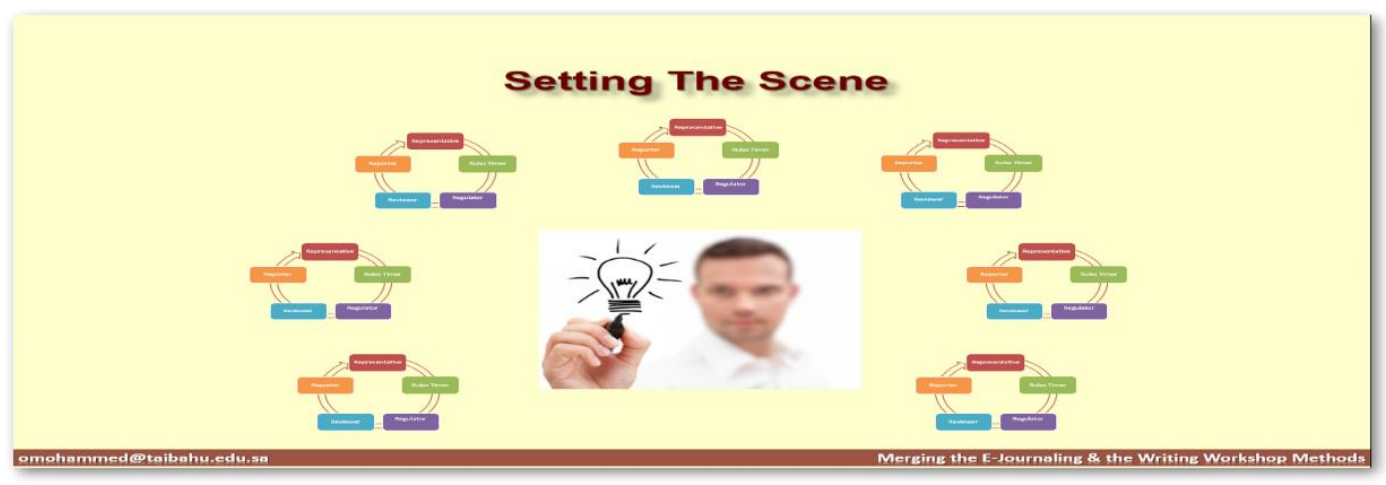

Figure (4) The communicative setting of student-student \& student-instructor interaction

The substantial reduction of the experimental group students' writing apprehension levels can also be correlated to the safe and positive environment the proposed program provided for the participants. For instance, the mistakes that students make were not stressed from the beginning as it was done in traditional approaches. Instead, it was stressed that mistakes were natural and expected from all humans, and they can be viewed as indicators of development that could be handled through the following stages of the writing process, so students did not have to worry about them. Also, the discussions and exchanges that took place during the writing conferences showed the students that they all can make mistakes and they all can learn from each other's mistakes as well. This played a vital role in lessening students' worry about making mistakes, which might have hindered their writing progress.

Another important feature of this program was the prewriting pedagogy which helped the students in overcoming their writers' blocks. These didactics made the students aware that each student has something to write about almost any topic. This helped them to start their topics and to overcome the fear of beginning to write inside them. Still, there was another important feature in this program that helped in minimizing the students' fear of writing, namely publishing activities, especially the author's circle technique. Students often did their best to finish their pieces in order to take their turns on the author's chair. They even asked to do this activity in every workshop session. The continuous encouragement and help made by the researcher helped the participants overcome their writing apprehension.

\section{Recommendations}

Based on the findings of the current study, the researcher recommends introducing this proposed methodology (merging the e-journaling and the writing workshop methods) to be used in teaching writing in prep-year and foundation university programs. It is also recommended that giving due focus to training teachers of English on using this new method. In addition, based on the results of the study we should introduce its applicable aspects and features to researchers, curriculum designers, and decision-makers in line with the following interpretations:

- Conducting more studies that aim at improving students' writing skills via different approaches using e-journaling/online writing practice. 


\section{Macrothink}

- Employing learning strategies, which motivate students and assist them to take on more responsibility for their own learning.

- Giving more confidence to learners in practicing EFL away from the classroom thru watching films and preparing projects and making research using online writing practice.

- Presenting the concept of pair and group work into writing classes instead of the traditional view of writing as an individual activity.

- Using student-centered pedagogy and retaining minimal intervention from the instructor.

- Presenting other forms of evaluation, namely self as well as peer evaluation.

- Encouraging learners to participate in real life social activities such as, interviewing some people in the local community and then write about it using e-journaling.

- Integrating prewriting activities into textbooks to maximize students' writing confidence.

- Incorporating interesting writing materials and pedagogies that hold the interest of students.

\section{References}

Abedi, P., Keshmirshekan, H., \& Namaziandost, E. (2019). The comparative effect of flipped classroom instruction versus traditional instruction on Iranian intermediate EFL learners' English composition writing. Journal of Applied Linguistics and Language Research, 6(4), 43-56.

Abrams, Z. (2019). The effects of integrated writing on linguistic complexity in L2 writing and task-complexity. System.

Agésilas, M. (2015). The Effectiveness of the Writing Workshop Model to Teach an English-as-a-Second-Language College Writing Course in Puerto Rico: A Look at Students' Outcomes.

Al-Ahmad, S. (2013). The impact of collaborative learning on L1 and L2 college students' apprehension about and attitudes toward writing. Unpublished doctoral dissertation, Indiana University of Pennsylvania, USA.

Al-Hroub A., Shami G., \& Evans M. (2019). The impact of the 'writers' workshop' approach on the L2 English writing of upper-primary students in Lebanon. The Language Learning Journal, 47(2), 159-171. https://doi.org/10.1080/09571736.2016.1249394

Al-Mohanna, A. (2010). English language teaching in Saudi Arabian context: How communicatively oriented is it? Journal of King Saud University, 22(1), 69-88.

Aly, M. (2002). The effect of using the writing workshop approach on developing student instructors composing skills. In Proceedings of the 21st CDELT National Symposium on 


\section{Macrothink}

English Language Teaching: Meeting Challenges of ELT in the Arab World (pp. 131-169).

Alzaanin, E. (2014). Investigating the pedagogical practices of EFL writing teachers in Palestinian universities: A cognitive-ecological perspective.

American Council on the Teaching of Foreign languages. (2017). ACTFL performance descriptors for language learners (2nd ed.). Alexandria: VA. Retrieved [4 Jun 2018] from: http://www.actfl.org/sites/default/files/pdfs/public/ACTFLProficiencyGuidelines2012_FI

Arju, S. (2019). Motivation Matters in Adopting Prewriting Strategies and Improving Writing Achievement Among Bangladeshi Adult EFL Learners. Journal of Asian and African Social Science and Humanities (ISSN 2413-2748), 4(4), 60-75.

Awan, R., Azher, M., Anwar, M., \& Naz, A. (2010). An Investigation of Foreign Language Classroom Anxiety And Its Relationship With Students Achievement. Journal of College Teaching \& Learning (TLC), 7(11). https://doi.org/10.19030/tlc.v7i11.249

Basha, N. (2012). Developing Learners' Academic Writing Skills in Higher Education: A Study for Educational Reform. Language \& Education,16(3), 161-177.

Badger, R., \& White, G. (2000). A process genre approach to teaching writing. ELT Journal, 54(2), 153-160.

Cargill M. (2019). The Value of Writing for Publication Workshops. In: Habibie P., Hyland K. (Eds.), Novice Writers and Scholarly Publication. Palgrave Macmillan, Cham.

Chen, T. (2016). Technology-supported peer feedback in ESL/EFL writing classes: A research synthesis. Computer Assisted Language Learning, 29(2), 365-397.

Chun, D., Kern, R., \& Smith, B. (2016). Technology in language use, language teaching, and language learning. Modern Language Journal, 100(S1), 64-80.

Ciampa, K. (2016). Implementing a digital reading and writing workshop model for content literacy pedagogy in an urban elementary (K-8) school. The Reading Instructor, 70(3).

Cohen, A. (2018). Reflections on a Career in Second Language Studies: Promising Pathways for Future Research. L2 Journal, 10(1).

Conhaim, W., \& Page, L. (2013). Personal journals: New users for an age-old practice. Information Today, 20(1), 27-31.

Creswell, J. (2009). Research design: Qualitative, quantitative and mixed methods approaches (3rd ed.). California: Sage.

Daly, J., \& Miller, M. (1975b). The empirical development of an instrument to measure writing apprehension. Research in the Teaching of English, 9(3), 242-249.

Dempsey, S., PytlikZillig, M., \& Burning, H. (2009). Helping Pre-service Instructors Learn to Assess Writing: Practice and Feedback in a Web-Based Environment. Assessing Writing, 14, 38-61. 


\section{Al Macrothink}

International Journal of English Language Education

ISSN 2325-0887

2020, Vol. 8, No. 1

Dyment, J., \& O'Connell, T. (2003). "Journal writing is something we have to learn on our own"-The results of a focus group discussion with recreation students. School: A Journal of Leisure Studies and Recreation Education, 18(1), 23-37.

ElSaid, M. (2006). The Effect of Using A programme Based on the Writing Workshop Approach on Writing skills and on the writing Apprehension of the second year Preparatory Student. Unpublished MA. Suhag Faculty of Education, South Valley University.

Gamboa, J., \& Buitrago, C. (2018). Optimizing the writing component of your EFL class through writing workshops. Technology in ELT: Achievements and challenges for ELT development, 113-130.

Gee, J. (2000). Discourse and sociocultural studies in reading. In Handbook on reading the research, volume III, edited by M. L. Kamil, P. B. Mosenthal, P. D. Pearson, \& R. Barr, 195208. London: Routledge.

Graham, S., \& Perin, D. (2018). Writing next: Effective strategies to improve the writing of adolescents in middle and high schools - A report to Carnegie Corporation of New York. Washington, DC: Alliance for Excellent Education.

Hassan, B. (2001). The Relationship of Writing Apprehension and Self-Esteem to the Writing Quality and Quantity of EFL University Students. Mansoura Faculty of Education Journal, 39, $1-36$.

Head, A., Glassman, E., Soares, G., Suzuki, R., Figueredo, L., D'Antoni, L., \& Hartmann, B. (2017). Writing reusable code feedback at scale with mixed-initiative program synthesis. In Proceedings of the Fourth (2017) ACM Conference on Learning@ Scale (pp. 89-98). ACM.

Hicks, T. (2013). Crafting digital writing: Composing texts across media and genre. Portsmouth, NH: Heinemann.

Hill, K. (2008). Scales and tests-competition or co-operation. Melbourne Papers in Language Testing, 4(2), 43-59.

Hodges, T. (2017). Theoretically Speaking: An Examination of Four Theories and How They Support Writing in the Classroom. The Clearing House: A Journal of Educational Strategies Issues and Ideas. 1-8. 10.1080/00098655.2017.1326228.

Huwari, I. (2014). Jordanian PhD students' EFL writing apprehension. PhD. thesis, University Utara Malaysia.

Kerr, A. (2017). Identifying Factors for Student Success in Micronesian Populations (Doctoral dissertation, Creighton University).

Khalil, A. (2016). Syntactic devices for marking information structure in English and Arabic. International Journal of Arabic-English Studies, 1(2), 133-156.

Kim, S. (2015). Preparing English learners for effective peer review in the writers' workshop. The Reading Instructor, 68(8), 599-603. 
Leer, E. B., \& Runck, B. C. (2016). Using writing workshop with English language learners. English Journal, 105(3), 107.

Lew, L., \& Tang, T. (2017). Beyond EFL writing anxiety: tapping into the individual emotionality of proficient EFL writers through semi-structured analysis and wearable sensing technology. Paper presented International Conference on Learning and Collaboration Technologies (pp. 170-181). Springer, Cham.

Lin, H. (2014). Establishing an empirical link between computer-mediated communication and SLA: A meta-analysis. Language Learning \& Technology, 18(3), 120-147. https://dx.doi.org/10125/44387

Massengill, M. (2001). Negotiating Transitions at Risk Students Adjustment from a Middle School Reading Workshop to Traditional High School English Class. DAL, 62(5), 1-16.

Matthews, D. (2016). In our voices: A pedagogical approach to reducing writing apprehension. Unpublished Doctoral Dissertation. The College of Arts and Sciences, Georgia State University.

Ministry of Education. (2018). General directorate of curricula: English for Saudi Arabia. Jeddah: AL Madinah AL Munawara Press.

Obeiah, S., \& Bataineh, R. (2016). Does scaffolding-based instruction improve writing performance? The case of Jordanian EFL learners. Lublin Studies in Modern Languages and Literature, 39(2), 106.

Peyton, K. (1994). Dialogue journals: Interactive writing to develop language and literacy. ERIC Document Reproduction Service, ED 354789.

Phinney, M. (1991). Word processing and writing apprehension in first and second language. Computer and Composition, 11(1), 65-82.

Rabab'ah, G. (2013). Communicating problems facing Arab learners of English. Journal of Language and Learning, 3(1), 180-197.

Rowen, D. (2005). The Write Motivation Using the Internet to Engage Students in Writing across the Curriculum. Language Arts. Learning \& Leading with Technology, 32(5), 22.

Sim, J., \& Hew, K. (2010). The use of weblogs in higher education settings: A review of empirical research. Educational Research Review, 5(2), 151-163.

Smith, R., \& Dirkx, J. (2007). Using consensus groups in online learning. New Directions for Adult and Continuing Education, 2007(113), 25-35.

Song, M. (2007). A promising practice for improving writing quality and decreasing writing apprehension of Korean students. Modern English Education, 8(2), 113-135.

Strobl, C. (2017). The potential of automated corrective feedback to remediate cohesion problems in advanced students' writing. In K. Borthwick, L. Bradley, \& S. Thousand (Eds.), CALL in a climate of change: adapting to turbulent global conditions - Short papers from 
EUROCALL 2017 (pp. 294-299). Research-publishing.net. Retrieved [23 Feb 2019] from https://research-publishing.net/publication/chapters/978-2- 490057-04-7/729.pdf

Tahaineh, S. (2015). Arab EFL university students' errors in the use of prepositions. MJAL, 2(1), 76-112.

Tuan, L. (2010). Enhancing EFL Learners' Writing Skill via Journal Writing. English Language Teaching, 3(3), 81-88.

Vandommele, G., Van den Branden, K., Van Gorp, K., \& De Maeyer, S. (2017). In-school and out-of- school multimodal writing as an L2 writing resource for beginner learners of Dutch. Journal of Second Language Writing, 36, 23-36.

White, E. (1991). Teaching and assessing writing: Recent advances in understanding, evaluating, and improving student performance (2ne ed.). San Francisco: Jossy- Bass Inc.

Wu, W., Yang, J., Scott C., Hsieh, J., \& Yamamoto, T. (2019). Free from demotivation in EFL writing: the use of online flipped writing instruction. Computer Assisted Language Learning, 1-35.

Zheng, B., \& Warschauer, M. (2018). Social media in the writing classroom and beyond. In J. I. Liontas (Ed.), The TESOL encyclopedia of English language teaching (pp. 1-5). New York, NY: Wiley-Blackwell.

\section{Copyright Disclaimer}

Copyright for this article is retained by the author(s), with first publication rights granted to the journal.

This is an open-access article distributed under the terms and conditions of the Creative Commons Attribution license (http://creativecommons.org/licenses/by/3.0/). 